\title{
Effect of Dietary Garlic Source on Feed Utilization, Growth and Histopathology of the African Catfish (Clarias gariepinus)
}

\author{
O. T. Agbebi ${ }^{1}$, T. G. Ogunmuyiwa ${ }^{1} \&$ S. M. Herbert ${ }^{1}$ \\ ${ }^{1}$ Department of Aquaculture and Fisheries Management, Federal University of Agriculture, Abeokuta, Ogun State, \\ Nigeria \\ Correspondence: O. T. Agbebi, Department of Aquaculture and Fisheries Management, Federal University of \\ Agriculture, Abeokuta, Ogun State, Nigeria. Tel: 234-803-704-5878, 234-807-272-3153. E-mail: \\ agbebi20@yahoo.com
}

Received: November 19, 2012 Accepted: February 28, 2013 Online Published: April 15, 2013

doi:10.5539/jas.v5n5p26

URL: http://dx.doi.org/10.5539/jas.v5n5p26

\begin{abstract}
The effects of garlic on the growth, survival and histology of Clarias gariepinus were examined during the period of eight weeks. One hundred and eighty (180) fingerlings with initial mean weight of $3.90 \pm 0.02$ were stocked at 15 fish per net happa $(0.8 \mathrm{~cm} \times 0.6 \mathrm{~cm} \times 0.4 \mathrm{~cm})$ suspended in an earthen pond of $(12 \mathrm{~m} \times 12 \mathrm{~m} \times 1.5 \mathrm{~m})$.

Triplicate groups of fish with garlic feed inclusion were fed at $3 \%$ body weight with four Iso-nitrogenous diet (40\% crude protein) in Treatment Diet1 (TD1) (control), Treatment Diet2 (TD2) 10\%, Treatment Diet3 (TD3) $20 \%$ and Treatment Diet 4 (TD4) 30\% respectively. At the end of the experiment, mean weight gain (MWG), Feed conversion ratio (FCR), specific growth rate (SGR), protein efficiency ratio (PER) and total protein consumed (TPC) were statistically close among the Treatments.

The highest MWG $(53.63 \pm 0.63)$ was recorded in fish fed with T4 while the lowest was recorded in fish fed T1 $(41.73 \pm 0.63)$. Specific growth ratio (SGR) was high in fish fed T4 (3.04 \pm 0.06$)$ and low in T3 (2.32 \pm 0.04$)$. The Treatment with the highest Feed conversion ratio (FCR) was T3 $(2.57 \pm 0.03)$ and the lowest was in T1 $(2.11 \pm$ $0.05)$. The overall best Treatment was Treatment 4 with $30 \%$ inclusion level of garlic source.

The histological examinations show no visible lesion in the liver and gut of all the Treatments except Treatment 3 with diffuse vacuolar degeneration of the hepatocytes, the gills in Treatment 4 has the epithelial cells of the secondary lamellae fused and proliferated.

Result obtained in this study indicated that $30 \%$ garlic inclusion rate in a compounded feed helps in feed utilization and growth Performance with no negative effect to the tissues.
\end{abstract}

Keywords: garlic, histology, fingerlings, iso-nitrogenous feed, treaments

\section{Introduction}

The supply of qualitative animal protein in sufficient quantity and at affordable cost has continued to remain a dream yet to be realized. It is a perennial problem and a major challenge to the livestock industry in most developing countries. High costs of feed due to shortage and unavailability of conventional feedstuffs for compounding livestock rations has been the major cause of rising cost of animal products (Sarkiyay, 2010).

Efforts aimed at increasing animal protein supply must necessarily address the competition between man and livestock for feed sources which has often resulted into shortage of such conventional feedstuffs like maize, soya beans and groundnut cake for compounding livestock feeds (Omage et al., 2008). This limitation imposed by scarcity of the conventional feedstuffs has made it necessary to source for alternative and cheaper feed materials to supply nutrients in livestock rations. Such materials would totally or partially substitute the expensive and relatively unavailable conventional feedstuffs and this will directly reduce production cost and improve profitability. It has been studied and reported that in intensive culture of fish breeding in which the fish are fed artificial feeds, the major recurring cost is the cost of feed which is about $60-75 \%$ of the operating cost for every cycle. The cost of feeding fish amounts to over two thirds of the operating cost of a fish culture in an intensive system (Eyo, 1990). Garlic is originating in Asia Minor and spontaneously grows in southern Europe, but in cultures, it could be found all over the world. It's a rich source of calcium, phosphorus and vitamin B1; it has a high content of carbohydrates and as a consequence a high nutritive value. Garlic also contains iodine salts which have 
a positive effect on the circulatory system and rheumatism, silicates which have a positive effect on the skeletal and circulatory system and sulfur salts with positive effects on the skeletal system, cholesterolemia, and liver diseases. Garlic also contains vitamin complex B, vitamins A, C and F (Drăgan, 2008).

Garlic has the following effects: lower the cholesterol and the triglycerides, ameliorates atherosclerosis, has a hypotensive, coronary dilator, antioxidant and anti cancer effect.

Garlic contains sulfur containing compounds. Alliin is converted to the anti-microbial active allicin, when the bulb is cut or bruised. Ajoene, which is a secondary degradation product of alliin, is presumably the most active compound responsible for the anti-thrombotic activity of garlic (Wichtl, 2004) the fresh bulb contains alliin, allicin and volatile oils. When the garlic clove is crushed, the odorless compound alliin is converted to allicin, via the enzyme allinase. Allicin gives garlic its characteristic pungent smell (Skidmore-Roth, 2003). Garlic has also been shown to have antioxidant properties, which could have a protective nature against gastrointestinal neoplasias, against blood clots (anti-platelet action) due in part to the compounds alliin and ajoene, which have fibrinolytic activity. Ajoene inhibits thromboxane synthesis through the inhibition of the cyclo-oxygenase and lipoxygenase enzymes (Schulz et al., 2004).

Therefore, this study aims to determine the utilization and additive nature of garlic in the feed with various inclusion levels and to examine the histopathological effect of garlic on the visceral organs of the fish species.

\section{Materials and Methods}

One hundred and eighty (Clarias gariepinus) fingerlings with average weight of $3.90 \pm 0.02 \mathrm{~g}$ were allowed to acclimatize to the environment for one week, and were starved for $24 \mathrm{hrs}$ prior to being placed on experimental system. Ten fingerlings randomly selected samples were sacrificed for carcass analysis before the commencement of the experiment.

The feeding trial was carried out in 12 net happas $(0.8 \mathrm{~m} \times 0.4 \mathrm{~m} \times 0.6 \mathrm{~m})$ suspended by bamboo poles with kuralon rope in an earthen pond of size ( $12 \mathrm{~m} \mathrm{x} 12 \mathrm{~m}$ x $1.5 \mathrm{~m})$. Each Treatment was replicated thrice with a control treatment. The swampy nature of the earthen pond had water recharging it from the underground water.

Fifteen (15) fish were selected randomly into each happa and weigh with the use of a sensitive weighing scale (METER TOLEDO FB602) and fed at 5\% of their body weight twice daily for a period of 8 weeks between the hours of 07:00-08:00 and 16:00-17:00 GMT. Fish were batch weighed weekly with a sensitive electronic scale and the feeds were adjusted accordingly with their increasing biomass, mortality was monitored daily.

Table 1. Experimental Layout

\begin{tabular}{llll}
\hline T1R3 & T2R2 & T3R2 & T2R1 \\
T3R3 & T3R1 & T4R2 & T1R1 \\
T4R3 & T2R3 & T4R1 & T1R2 \\
\hline
\end{tabular}

Treatment 1- control diets ( $0 \%$ inclusion); Treatment 2- Garlic (10\% inclusion); Treatment 3- Garlic (20\% inclusion); Treatment 4- Garlic (30\% inclusion).

Table 2. Ingredient composition of experimental feed diet

\begin{tabular}{lllll}
\hline Ingredients & T1 & T2 & T3 & T4 \\
\hline Maize & 29.67 & 30.10 & 30.45 & 31.47 \\
Fish meal & 27.03 & 26.84 & 26.64 & 26.43 \\
Groundnut cake & 27.03 & 26.59 & 25.54 & 23.43 \\
Soybean meal & 13.52 & 13.42 & 13.32 & 13.22 \\
Garlic & - & 0.3 & 1.2 & 2.8 \\
Vit. Premix & 1 & 1 & 1 & 1 \\
Dicalcium & 0.5 & 0.5 & 0.5 & 0.5 \\
phosphate & 0.5 & 0.5 & 0.5 & 0.5 \\
Lysine & 0.5 & 0.5 & 0.5 & 0.5 \\
Methionine & 0.25 & 0.25 & 0.25 & 0.25 \\
Salt & 100.00 & 100.00 & 100.00 & 100.00 \\
Total & & & & \\
\hline
\end{tabular}


Table 3. Proximate composition of experimental feed diet

\begin{tabular}{lcccc}
\hline Parameters & T1 & \multicolumn{1}{c}{ T2 } & T3 & \multicolumn{1}{c}{ T4 } \\
\hline Moisture & $7.6 \pm 0.01^{\mathrm{c}}$ & $6.9 \pm 0.01^{\mathrm{d}}$ & $8.33 \pm 0.01^{\mathrm{b}}$ & $8.6 \pm 0.01^{\mathrm{a}}$ \\
Dry & $92.98 \pm 0.02^{\mathrm{b}}$ & $93.1 \pm 0.06^{\mathrm{a}}$ & $91.66 \pm 0.01^{\mathrm{c}}$ & $91.4 \pm 0.01^{\mathrm{d}}$ \\
Fat & $19.57 \pm 0.01^{\mathrm{a}}$ & $15.52 \pm 0.05^{\mathrm{c}}$ & $15.28 \pm 0.01^{\mathrm{d}}$ & $16.13 \pm 0.01^{\mathrm{b}}$ \\
Ash & $9.26 \pm 0.01^{\mathrm{a}}$ & $8.35 \pm 0.01^{\mathrm{b}}$ & $8.11 \pm 0.00^{\mathrm{c}}$ & $7.92 \pm 0.01^{\mathrm{d}}$ \\
F.C & $29.54 \pm 10.34$ & $38.04 \pm 0.02$ & $36.71 \pm 0.12$ & $36.62 \pm 0.01$ \\
C.P & $3.56 \pm 0.01^{\mathrm{a}}$ & $2.26 \pm 0.03^{\mathrm{b}}$ & $2.16 \pm 0.01^{\mathrm{c}}$ & $2.06 \pm 0.01^{\mathrm{b}}$ \\
CHO & $28.91 \pm 0.01^{\mathrm{b}}$ & $29.95 \pm 0.05^{\mathrm{b}}$ & $29.41 \pm 0.02^{\mathrm{c}}$ & $30.67 \pm 0.01^{\mathrm{a}}$ \\
\hline
\end{tabular}

Means along the same row with different superscripts are significantly different $(\mathrm{p}<0.05)$.

\subsection{Growth Performance}

$$
\begin{aligned}
\text { Percentage weight gain PWG }(\%) & =\frac{(\text { Final mean body weight })}{(\text { Initial mean body weight })} \times 100 \\
\text { Specific growth rate, SGR } & =\frac{\text { Ln W2 }- \text { LnW1 } \times 100}{\text { Time (days) }}
\end{aligned}
$$

$\mathrm{W} 1=$ initial weight gained; W2= Final weight gained; $\mathrm{Ln}=$ Natural logarithm .

$$
\begin{gathered}
\text { Protein efficiency ratio }=\frac{\text { Mean weight gain }}{\text { Average protein fed }} \\
\text { Feed conversion ratio }=\frac{\text { weight of feed }(\mathrm{g})}{\text { Weight gained }} \\
\text { Mortality rate }=\frac{\text { No of fish dead at the end of the experiment }}{\text { No of fish at the beginning of the experiment }} \times 100 \\
\text { Survival rate }=\frac{\text { No of fish remaining at the end of the experiment }}{\text { No of fish at the beginning of the experiment }} \times 100
\end{gathered}
$$

Feed conversion ratio, FCR this is obtained by dividing the total weight of the food administered the total increase in weight gained by the fish over a period of time.

$$
\mathrm{SGR}=\frac{\mathrm{Ln} \mathrm{W} 2-\mathrm{LW} 1}{\text { Time (days) }} \mathrm{X} 100
$$

$\mathrm{W}_{1}=$ Initial weight gain; $\mathrm{W}_{2}=$ Final weight gain; $\mathrm{L}_{\mathrm{n}}=$ Natural logarithm; Time $=$ Number of days of experiment

\section{Results and Discussion}

$$
\text { PER }=\frac{\text { Fish weight gain }}{\text { Protein gain }}
$$

The initial and final carcass analysis of the fish is represented in Table 3.

Table 4. Carcass Analysis of experimental fish

\begin{tabular}{llllll}
\hline Parameters & Initial & T1 & T2 & T3 & T4 \\
\hline Moisture & $78.62 \pm 0.30^{\mathrm{c}}$ & $71.96 \pm 0.01^{\mathrm{d}}$ & $81.41 \pm 0.01^{\mathrm{b}}$ & $81.56 \pm 0.01^{\mathrm{b}}$ & $85.03 \pm 1.67^{\mathrm{a}}$ \\
Dry & $21.38 \pm 0.01^{\mathrm{a}}$ & $18.54 \pm 0.01^{\mathrm{c}}$ & $18.59 \pm 0.03^{\mathrm{b}}$ & $18.61 \pm 0.01^{\mathrm{b}}$ & $16.64 \pm 0.01^{\mathrm{a}}$ \\
Fat & $2.79 \pm 0.05^{\mathrm{b}}$ & $6.45 \pm 0.12^{\mathrm{a}}$ & $2.42 \pm 0.01^{\mathrm{c}}$ & $1.76 \pm 0.01^{\mathrm{d}}$ & $1.45 \pm 0.01^{\mathrm{e}}$ \\
Ash & $1.44 \pm 0.01^{\mathrm{c}}$ & $2.17 \pm 0.01^{\mathrm{a}}$ & $1.55 \pm 0.01^{\mathrm{b}}$ & $1.26 \pm 0.01^{\mathrm{a}}$ & $1.12 \pm 0.02^{\mathrm{e}}$ \\
F.C & $0.98 \pm 0.21^{\mathrm{a}}$ & $1.08 \pm 0.01^{\mathrm{a}}$ & $1.06 \pm 0.00$ & $1.02 \pm 0.01^{\mathrm{b}}$ & $1.00 \pm 0.01^{\mathrm{a}}$ \\
C.P & $37.84 \pm 0.17^{\mathrm{c}}$ & $41.62 \pm 0.08^{\mathrm{a}}$ & $39.44 \pm 0.01^{\mathrm{b}}$ & $39.28 \pm 0.01^{\mathrm{b}}$ & $38.03 \pm 0.01^{\mathrm{c}}$ \\
CHO & $1.22 \pm 0.05^{\mathrm{a}}$ & $0.92 \pm 0.01^{\mathrm{a}}$ & $1.08 \pm 0.00^{\mathrm{bc}}$ & $1.12 \pm 0.01^{\mathrm{b}}$ & $1.04 \pm 0.01^{\mathrm{c}}$ \\
\hline
\end{tabular}

Means along the same row with different superscripts are significantly different $(\mathrm{p}<0.05)$. 
The moisture content of the fish carcass obtained after the experiment was high in three Treatments compared to the initial value. Treatment 1 was the lowest (71.96\%), followed by Treatment $2(81.41 \%)$, and Treatment 4 having the highest moisture content $(85.03 \%)$. However, Treatment 1 recorded the highest crude protein $(41.62 \%)$ and the lowest was recorded in Treatment $4(38.03 \%)$. Final Carbohydrate of fish carcass ranged between $0.92 \%$ in Treatment 1 to $1.12 \%$ in Treatment 3 . The final dry matters in all the Treatments are lower than the initial values.

Table 5 shows the growth response of fish to different Garlic inclusions in the feed and the mean weekly values of physico-chemical parameters during the experiment are represented in Table 6

Table 5. Growth response of fish to different Garlic inclusion in the feed

\begin{tabular}{lllll}
\hline Parameters & 0\% Inclusion & $10 \%$ Inclusion & $20 \%$ Inclusion & 30\% Inclusion \\
& T1 & T2 & T3 & T4 \\
\hline Initial Weight (g/fish) & $3.90 \pm 0.02$ & $3.90 \pm 0.04$ & $3.90 \pm 0.03$ & $3.90 \pm 0.02$ \\
Final Weight (g/fish) & $35.00 \pm 2.32^{\mathrm{a}}$ & $79.36 \pm 1.92^{\mathrm{c}}$ & $80.49 \pm 0.29^{\mathrm{b}}$ & $86.10 \pm 0.39^{\mathrm{d}}$ \\
Weight Gain (g/fish) & $41.73 \pm 0.63^{\mathrm{a}}$ & $43.96 \pm 2.38^{\mathrm{c}}$ & $43.96 \pm 0.93^{\mathrm{a}}$ & $53.63 \pm 0.63^{\mathrm{b}}$ \\
AFC (g/fish/day) & $105.71 \pm 0.14^{\mathrm{b}}$ & $155.43 \pm 0.57^{\mathrm{c}}$ & $103.9 \pm 0.71^{\mathrm{a}}$ & $159.58 \pm 0.4^{\mathrm{d}}$ \\
FCR & $2.51 \pm 0.01^{\mathrm{c}}$ & $2.33 \pm 0.02^{\mathrm{b}}$ & $2.38 \pm 0.02^{\mathrm{a}}$ & $2.11 \pm 0.05^{\mathrm{a}}$ \\
SGR & $2.32 \pm 0.04^{\mathrm{a}}$ & $2.79 \pm 0.02^{\mathrm{b}}$ & $2.38 \pm 0.02^{\mathrm{a}}$ & $3.04 \pm 0.06^{\mathrm{d}}$ \\
TPC & $33.19 \pm 0.59^{\mathrm{a}}$ & $55.62 \pm 1.86^{\mathrm{d}}$ & $37.77 \pm 0.39^{\mathrm{b}}$ & $55.26 \pm 0.02^{\mathrm{d}}$ \\
PER & $0.75 \pm 0.03^{\mathrm{a}}$ & $0.85 \pm 0.01^{\mathrm{b}}$ & $0.91 \pm 0.01^{\mathrm{d}}$ & $0.72 \pm 0.01^{\mathrm{a}}$ \\
Survival & $50.77 \pm 0.33^{\mathrm{a}}$ & $65.94 \pm 0.44^{\mathrm{b}}$ & $70.40 \pm 0.35^{\mathrm{c}}$ & $72.71 \pm 0.61^{\mathrm{d}}$ \\
\hline
\end{tabular}

Means along the same row with different superscripts are significantly different $(\mathrm{p}<0.05)$;

AFC: Average Feed Consumed, FCR: Feed Conversion Ratio, SGR: Specific Growth Rate, TPC: Total Protein Consumed, PER: Protein Efficiency Ratio.

In Table 5, Treatment 4 with 30\% garlic inclusion level had the highest final weight per fish $(86.10 \pm 0.39 \mathrm{~g})$, followed by Treatment 3 with $20 \%(80.49 \pm 0.29 \mathrm{~g})$ and the least in (control) Treatment 1 with $0 \%$ inclusion $(35.00 \pm 2.35 \mathrm{~g})$, and all Treatments were significant $(\mathrm{p}<0.05)$.

The Average feed consumed/fish/day was significantly different $(\mathrm{p}<0.05)$ with the highest value in Treatment 4 $(159.59 \pm 0.4)$, followed by Treatment $2(155.43 \pm 0.57)$, Treatment $1(105.71 \pm 0.41)$ and the least was Treatment $3(103.9 \pm 0.71)$.

Treatment $4(2.11 \pm 0.05)$ had the best feed conversion ratio followed by Treatment $2(2.33 \pm 0.02)$ and $3(2.38 \pm$ $0.02)$, the least in Treatment $1(2.51 \pm 0.41)$.

The specific growth rate was significantly different $(\mathrm{p}<0.05)$ in Treatment $4(3.04 \pm 0.06)$ and Treatment $2(2.79$ $\pm 0.02)$ while there was no significant different $(\mathrm{p}>0.05)$ in Treatment $3(2.38 \pm 0.02)$ and Treatment $1(2.32 \pm$ $0.04)$ respectively.

There was a significant difference $(\mathrm{p}<0.05)$ in the protein efficiency ratio in Treatment $3(0.91 \pm 0.01)$ and Treatment $2(0.85 \pm 0.01)$. This agrees with the work of Gabor (2010) on the effects of Some Phytoadditives on Growth, Health and Meat Quality on Different Species of Fish.

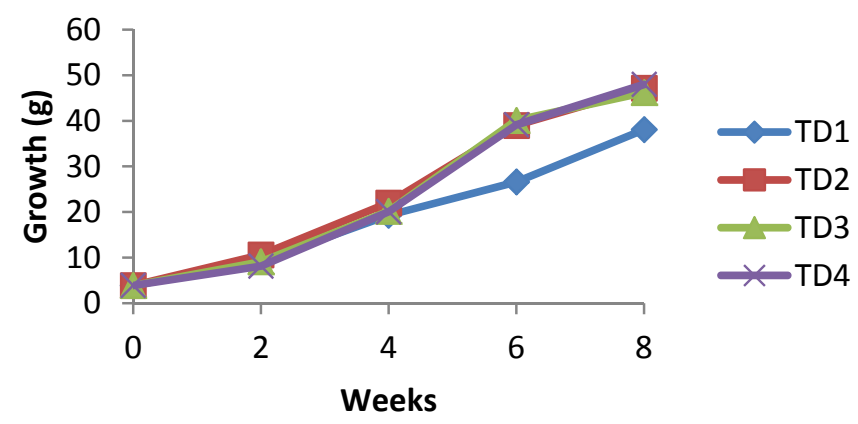

Figure 1. Growth response of C.gariepinus fingerlings fed with garlic base diets for eight weeks 


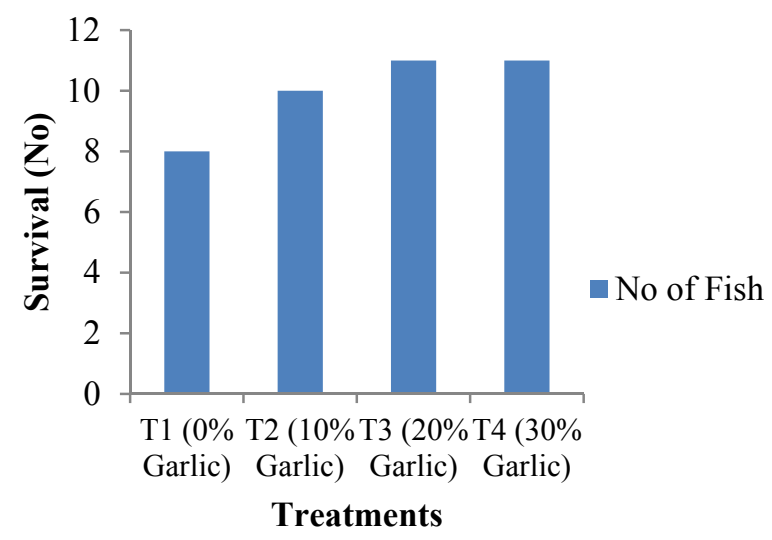

Figure 2. Mean survival rate of different treatments

There was significant difference $(\mathrm{p}<0.05)$ in the survival rate of Clarias gariepinus fingerlings fed varying inclusion levels of garlic for the 8 weeks. The highest survival was obtain in Treatment 4 (72.71 \pm 0.61$)$, followed by Treatment $3(70.40 \pm 0.35)$, Treatment $2(65.94 \pm 0.44)$ and the least in Treatment $1(50.77 \pm 0.33)$. This was in support by Ashraf (2008) finding on survival of Clarias gariepinus in a net happa suspended in an earthen pond with varying stocking density. Increase in garlic inclusion of feed resulted in higher fish survival. This is similar to the findings of Ayotunde et al. (2005) in the work on toxicity of aqueous extract of drumstic, Moringa oleifera, to fingerling and adult catfish Clarias gariepinus. The mean survival rate of Treatments at the end of the experiment was highest in Treatment 4 (73\%) while the lowest was recorded in Treatment 1 (51\%).

Table 6. Mean weekly values of physico-chemical parameters during the experimental period

\begin{tabular}{llll}
\hline Weeks & $\mathrm{pH}$ & Dissolve oxygen $(\mathrm{Mg} / \mathrm{L})$ & Temp $\left({ }^{\circ} \mathrm{C}\right)$ \\
\hline 0 & $7.20 \pm 0.06$ & $6.17 \pm 0.03$ & $26.00 \pm 1.15$ \\
1 & $7.31 \pm 0.12$ & $6.30 \pm 0.20$ & $26.53 \pm 0.27$ \\
2 & $7.45 \pm 0.32$ & $6.23 \pm 0.33$ & $27.17 \pm 0.33$ \\
3 & $7.41 \pm 0.11$ & $6.53 \pm 0.13$ & $27.37 \pm 0.07$ \\
4 & $7.25 \pm 0.43$ & $7.40 \pm 0.80$ & $26.40 \pm 0.35$ \\
5 & $7.15 \pm 0.20$ & $7.47 \pm 0.73$ & $28.01 \pm 0.39$ \\
6 & $7.55 \pm 0.55$ & $7.25 \pm 0.14$ & $27.71 \pm 0.19$ \\
7 & $7.26 \pm 0.20$ & $7.33 \pm 0.33$ & $27.44 \pm 1.12$ \\
8 & $7.80 \pm 0.30$ & $7.40 \pm 0.20$ & $26.78 \pm 0.77$ \\
\hline
\end{tabular}

The Mean weekly values of physico-chemical parameters during the experimental periods were within the acceptable range of rearing Clarias gariepinus. This conforms to the result of Adekoya et al. 2004 and FAO, 1992 recommended values for a successful catfish production system.

\section{Statistical Analysis}

All data obtained were subjected to one-way ANOVA test Where ANOVA revealed significant differences $(\mathrm{P}<$ 0.05), Duncan's multiple-range test (Zar, 1996) was applied to characterize and quantify the differences between treatments using SAS software for windows (SAS, 2009). 


\subsection{Histopathology (Control)}

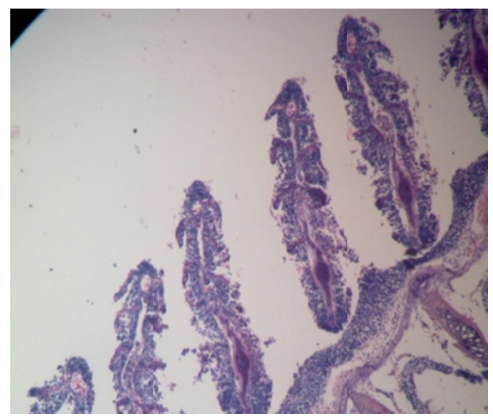

Plate 8

Gill (TD1)

No visible lesion (No physical damage)

\subsection{Treatment 2}

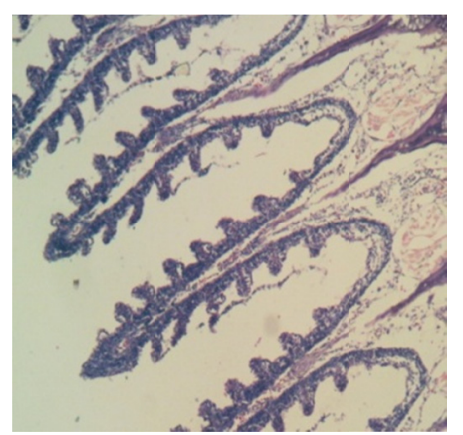

Plate 11

Gill

No visible lesion (No physical damage)

\subsection{Treatment 3}

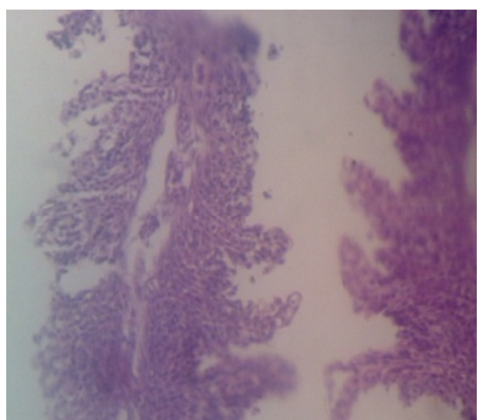

Plate 14

Gill

Moderate diffuse proliferates or Hyperplasia of the second lamellae With vacuolation of the epithelial cells

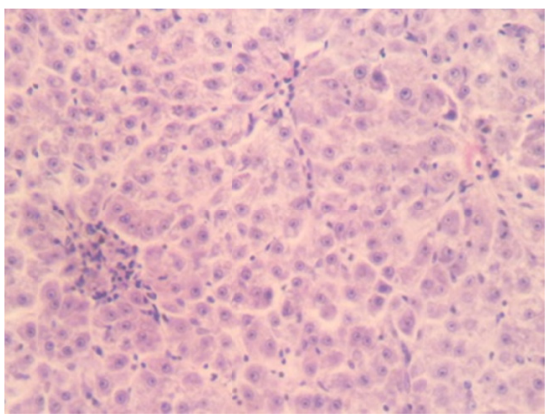

Plate 9

Liver (TD1)

No visible lesion (No physical damage)

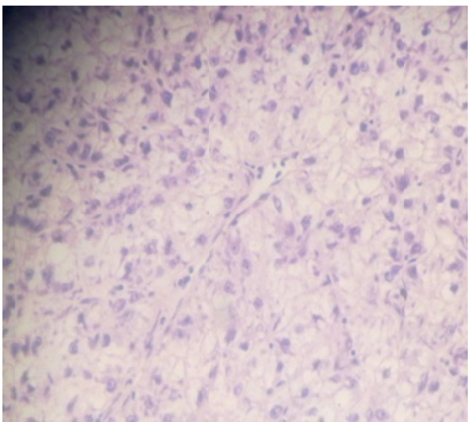

Plate 12

Liver

No visible lesion (No physical damage)

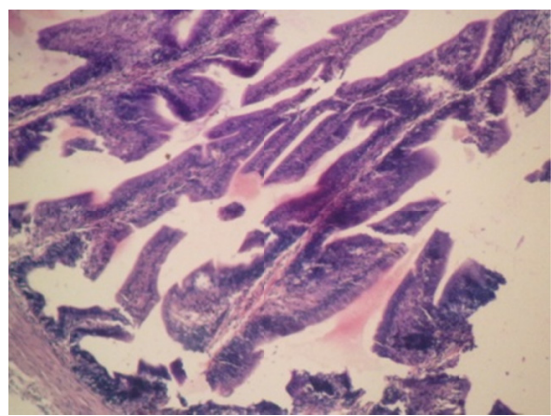

Plate 10

Gut ( TD1)

No visible lesion (No physical damage)

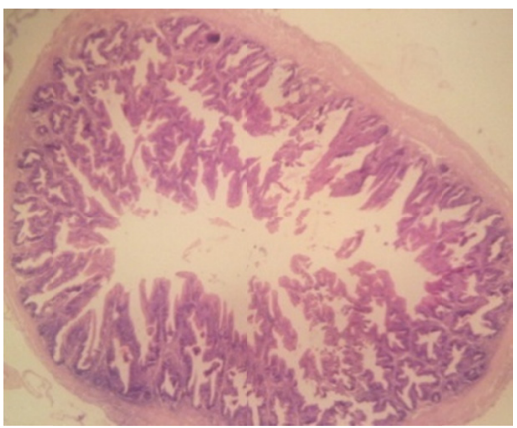

Plate 13

Gut

No visible lesion (No physical damage)

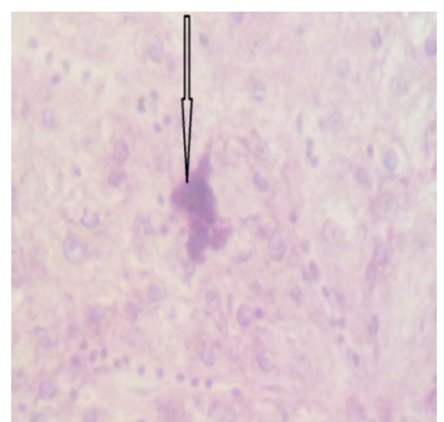

Plate 15

Liver

Moderate diffuse vascular degeneration

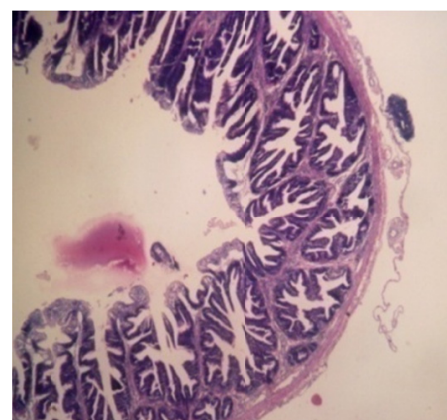

Plate 16

Gut

No visible lesion (No physical damage) 


\subsection{Treatment 4}

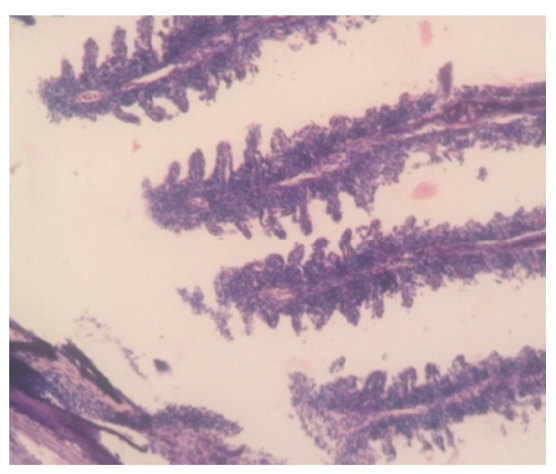

Plate 17

Gill

Fusion and proliferation of the gill

Epithelial cell of the ill lamillae

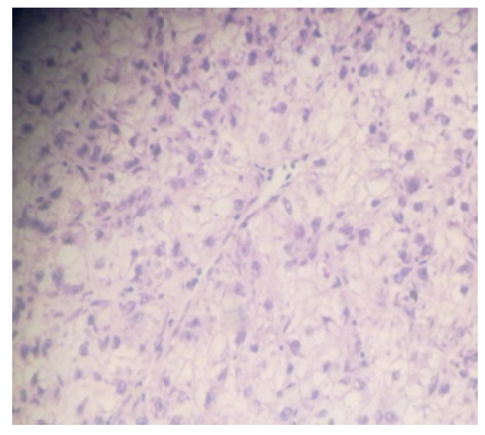

Plate 18

Liver

(No visible lesion i.e. no physical damage)

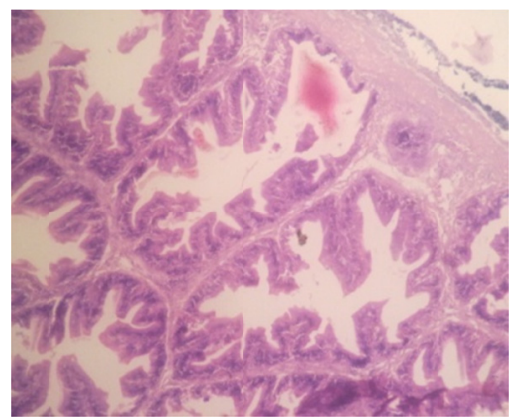

Plate 19

Gut

(No visible lesion i.e no physical damage)

\subsection{Histopathology of the Gills}

The gills participate in many important functions in the fish such as respiration, osmoregulation and excretion. The result in Treatment 1 (plate 8) and Treatment 2 (plate 11) shows no visible lesion i.e. physical damage in the gills which conform to the submission of Hassan et al. (2007), The finding was related to Anthonio et al. (2007) in the work on the histopathological changes in the normal gills epithelium of Nile Tilapia (O. niloticus) exposed to waterborne copper.

The lesion in the gills of Treatment 3 (plate 14) was manifested in the $20 \%$ inclusion level. The anomalies include diffuse proliferated hyperplasia of the secondary lamellae with vacuolation of the epithelial cells i.e. an unusual growth in a part of secondary lamellae caused by excessive multiplication of the cells. This is similar to the work of Sayed et al. (2007) on the histopathological alterations in the gills of adult catfish exposed to 4-Nonylphenol.

Treatment 4 (plate 17) shows gills with fusion and proliferation of the epithelial cells of the gills lamellae. This is similar to the findings of Dutta et al. (1996), where there were many alterations such as increase in mucous and chlorine cell number and size, necrosis, rupture of epithelium, desquamation, deformed secondary lamellae and Oedema.

Pleuranen et al. (1994), any discontinuity of epithelial lining of the gill lead to a negative ion balance and to changes in the haematocrite and mean cellular haemoglobin values of the blood.

Part et al. (1985) noticed similar result in the histology of the gills of rainbow trout where there was increased ion permeability and sodium efflux of gill epithelial cells due to ethoxylate nonyphenol.

\subsection{Histopathology of the Liver}

The liver is an organ most associated with the detoxification, biotransformation process and functions as blood supply due to its position (Carmago, 2011).

In the present study, Treatment 1 (plate 9), Treatment 2 (plate 12) and Treatment 4 (plate 18) shows no visible lesion in the liver. They possess normal histological structures of the liver.

Examination of the liver section of Treatment 3 (plate 15) shows moderate diffuse vascular degeneration of the hepatocytes resulting in the loss of ability of the fluid carrying vessel to deteriorate thereby reducing its function.

Similar results were recorded by Uguz et al. (2003) who reported a significant increase in the kupffer cells after one week of 4-Nonylphenol exposure. Hughes et al. (2000) and Uguz et al. (2003) reported that the disappearance of the cell membranes in the liver could be due to the lytic activity of alkylphenols.

\subsection{Histopathology of the Gut}

The result shows normal gut in all the treatments examined. Treatment 2 (plate 13), Treatment 3 (plate 16) and Treatment 4 (plate19) shows no visible lesion. No alterations in the gut of all the treatments administered with different level of garlic as observed in Treatment 1 (Control). 
This is in agreement with the findings of (Fatma, 2009) in the work histopathogical studies on Tilapia zillii and Solea vulgaris from Lake Quarum.

Ayotunde et al. (2011), observed no visible lesion on control fish in the work histological changes in O.niloticus exposed to Aqueous extract of Moringa oleifera seeds powder.

\section{Conclusion}

Results show that garlic can be conveniently used as a complete phyto-additives in fish diet of African catfish (Clarias gariepinus). In general, the results obtained showed no negative effect on the growth of African catfish and histology of the viscera organs suggesting that it is essentially good for growth and utilization.

From the results, it is clear that there was no negative impact on the survival rate in the use of garlic and there was efficient utilization of feed on weight gain, total protein consumed, feed conversion ratio and moderate feed intake. The significant of the research to fish farmers is that natural growth promoters have fewer disadvantages compared to artificial growth promoters for artificial growth promoters could be bio-accumulated to the final consumers.

\section{Recommendation}

For suitable aquaculture practices, majorly in developing countries where the level of awareness on fish drug is low, the use of garlic at higher level $30 \%$ is recommended, for the highest inclusion gave the best result.

Further study should be carried out on the most suitable phyto-additives for efficient utilization and immune activity with corresponding analysis on their tissue and blood compositions.

There could be trial on higher inclusion level from $40 \%$ upward to further ascertain the maximum possible derivable garlic additive limit in fish compounded feeds.

\section{References}

Adekoya, B. B., Olunuga, O. A., Ayansanwo, T. O., \& Omoyinmi, G. A. K. (2004). Manual of the second annual seminar and training workshop held at Ogun State Agriculture development Programme, OGADEP, Olabisi Onabanjo Way, Idi Aba, Abeokuta. Publisher: The Fisheries Society of Nigeria (Ogun State Chapter).

Antonio, F. F., Jorge, V. F. C., Sofia, G. S., Sandra, M. M., Joao, C., Pedro, M., \& Antonio, F. F. (2007). Histopathological changes in liver and gills epithelium of Nile tilapia, Oreochromis niloticus, exposed to waterborne copper. Pesq. Vet. Bras. Marco, 27(3), 103-109.

Ashraf, M. A., \& Goda, S. (2008). Effect of dietary Ginseng herb (Ginsana G115) supplementation on growth, feed utilization, and hematological indices of Nile Tilapia, Oreochromis niloticus (L.), fingerlings. $J$ World Aquac Soc, 39(2), 205-214. http://dx.doi.org/10.1111/j.1749-7345.2008.00153.x

Ayotunde, E. O., Fagbenro, O. A., \& Adebayo, O. T. (2011). Histological Changes in Oreochromis niloticus (Linnaeus 1779) Exposed to Aqueous Extract of Moringa oleifera Seeds Powder. Turkish Journal on Fisheries and Aquatic Sciences, 11,37-43

Camargo, M. M., \& Martinez, C. B. (2007). Histopathology of gills, kidney and liver of a Neotropical fish caged in an urban stream. Neotrop Ichthyol., 5, 327-336. http://dx.doi.org/10.1590/S1679-62252007000300013

Diegane, N, \& Jean, F. (2011). The effect of garlic (Allium sativum) on growth and immune responses of hybrid tilapia (Oreochromis niloticus x Oreochromis aureus) J. Clinical Immunology and Immunopathology Research, 3(1), 1-9.

Drăgan, S., Gergen, I., \& Socaciu, C. (2008). Alimentația funcțională cu componente bioactive naturale în sindromul metabolic. Ed. Eurostampa, Timişoara, 200-202.

Eyo, A. A. (1994). The requirement for formulating standard artificial fish feed. Paper presented at the 11th annual Conference of the fisheries society of Nigeria (FISON) held at the Lagos State Auditorium Secretariat Alausa, Ikeja, Lagos State, 22nd-24th February, 1994, p.15.

FAO. (1996). Artificial reoroduction and pond rearing of the African catfish Clarias gariepinus in Saharan African. FOA FISHERIES TECHNICAL PAPER_NO. 362.

Fatma, A. S. (2009). Histopathological Studies on Tilapia zillii and Solea vulgaris from lake Quarun, Egypt. National Institute of Oceanography and Fisheries, Inland Water and Aquaculture Branch.

Gabor, E. F., Şara, A., \& Barbu, A. (2010). The Effects of Some Phytoadditives on Growth, Health and Meat Quality on Different Species of Fish. Animal Science and Biotechnologies, 43(1). 
Hughes, P. J., McLellan, H., Lowes, D. A., Khan, S. Z., Bilmen, J. G., Torey, S. C., ... Michelangeli, F. (2000). Estrogenic Alkylphenols Induce Death by Inhibiting Testis Endoplasmic Reticulum Ca ${ }^{2+} \mathrm{Pumps}$. Biochemical and Biophysical Research Communications, 277, 68-574. http://dx.doi.org/10.1006/bbrc.2000.3710

Lawal, O. T. (2011). Effects of Replacing Dietary Fish Oil on Growth Response of African Catfish, Clarias gariepinus Fingerlings. Federal University of Agriculture, Abeokuta

Omage, J. J., Onimisi, P. A., Adegbite, E. K., \& Agunbiade, M. O. (2007). The Effect of Ginger (Zingiber officinale Roscoe) Waste Meal on Growth Performance, Carcass Characteristics, Serum Lipid and Serum Cholesterol Profiles of Rabbit. Pakistan Journal of Nutrition, 6(4), 359-362. http://dx.doi.org/10.3923/pjn.2007.359.362

Part, P., Svanberg, O., \& Bergstrom, E. (1985). The influence of Surfactants on gills Physiology and Cadmium Uptake in Perfuse Rainbow Trout gills. Ecotoxicology and Enviromental Safety, 9, $135-144$. http://dx.doi.org/10.1016/0147-6513(85)90016-8

Pleuranen, S., Vuorinen, P. J., Vuorinen, M., \& Hollender, A. (1994). The effect of iron, humicacids and low pH on the gills and physiology of brown trout (Salmo trutta). Annales Zoologici Fennicii, 31, 389-396.

Sarkiyay, S., \& Agar, T. M. (2010). Comparative Analysis on the nutritional and antinutritional contents of the sweet and bitter cassava varieties. Advance journal of food science and technology, 2(6), 328-1084.

SAS. (1999). SAS, version 8, SAS Institute Inc., Cary, NC, USA.

Sayed, A. H., Mekkawy, I. A., \& Mammoud, U. M. A. (2011). Histopathological Alterations in Some Body organs of Adult Clarias gariepinus (Burchell, 1882) Exposed to 4-Nonylphenol. The 19th Conference of Egyptian German Scocity of Zoology, Bin Sueif University, Egypt.

Schulz, V., Hansel, R., Tyler, V., \& Blumenthal, M. (2004). Rational Phytotherapy: A Physician's Guide (5th ed.). Berlin: Springer-Verlag.

Shalaby, A. M., Khattab, Y. A., Abdel, R. A. M. (2006). Effects of garlic (Allium sativum) and chloramphenicol on growth performance, physiological parameters and survival of Nile tilapia (Oreochromis niloticus). J. Venom. Anim. Toxins incl. Trop. Dis., 12(2), 172-201.

Skidmore-Roth, L. (2003). Handbook of Herbs and Natural Supplements (2nd ed.). St. Louis: Mosby.

Uguz, C., Iscan, M., Ergu, A., Belgin, I. V., \& Togan, I. (2003). The Bioaccumulation of Nonylphenol and its adverse Effect on The Liver of Rainbow Trout (Onchorychus mykiss). Enviromental Research, 92, 262-270. http://dx.doi.org/10.1016/S0013-9351(03)00033-1

Wichtl, M. (2004). Herbal Drugs and Phytopharmaceuticals (3rd ed). Boca Raton, FL: CRC Press.

Zar, J. H. (1996). Biostatistical Analysis (3rd ed.). Prentice-Hall, Upper Saddle River, New Jersey, USA. 